\title{
Ready Made Garments' (RMG) Contribution in Women Empowerment: A Study on Bangladesh Perspective
}

\author{
Mohammed Masum Billah \\ Assistant Professor, Department of Business Administration, \\ BGMEA University of Fashion and Technology (BUFT), Bangladesh \\ Md. Rafiqul Islam Manik \\ Lecturer, Department of Knitwear Manufacture \& Technology, \\ BGMEA University of Fashion and Technology, Bangladesh
}

Doi: 10.19044/esj.2017.v13n29p184 URL:http://dx.doi.org/10.19044/esj.2017.v13n29p184

\begin{abstract}
There is no denying the fact that without women empowerment development goals of Bangladesh is always unreachable. This country belongs to a social system where women consider as a burden for the family. However, the scenario is changing with time. Nowadays, women are working in garments sector, education sector, banking sector, different NGO's and government organizations but the single garment sector where seventy percent of workers of 4.0 million are women and most of them are less educated, unskilled and from rural areas. These women have neither decision making power and nor access to resources before getting the job in the garments sector. The job creates ample opportunity for female workers by giving economic freedom, keeping them near the resources and facilities in the city area, and making them knowledgeable, and skills through training, counseling, and sharing problem with coworkers. The study reveals that empowerment of women vastly depends on four variables which are women's financial contribution to family, women's access to resources, women's participation in household decision making and their perception of coping capacity to shocks. It has been found that garments sector significantly contribute to enhance the female worker's ability to contribute financially, to participate in decision making, to access resources, and to cope with risks which ultimately increase their empowerment in the society as a whole.
\end{abstract}

Keywords: Empowerment, Decision Making, Risks, Participation 


\section{Introduction}

Women empowerment is the precursor of poverty elimination and uplifting human rights in Bangladesh where half of the population is women. Social oppression and economic inequality creates unfavorable situations for rural women who are actually belonging to extremely poor income group (DFID, 2000). As a patriarchal society, men have supreme authority to control both households and society whereas women generally kept in their house (Balk, 1997).

Women's are becoming vulnerable in Bangladesh because of their less access to household resources, poor knowledge and skills, huge domestic workloads, and limited part in household decision making (Sebstad and Cohen 2002). In Bangladesh, women's are unequally treated by the family members and sometimes restrict them to go outside such as to join garment sector which means women have no voice in the family (Cain et al, 1979).

Bangladesh RMG sector plays a significant role to reduce poverty and to increase women empowerment. RMG industry has been swaggering in the country since long time as a catalyst for sustainable development and growth. The RMG employees around 4.0 million people directly, $70 \%$ of them women. This sector has created a platform for 2.8 million women to engage in new productive role in the society and empowering the poor. The apex body of country's leading export item, Bangladesh Garments Manufacturers \& Exporters Association has total number of 4300 members out of which 1720 factories are Knitwear and sweater manufacturers and around 2580 factories are woven garments manufacturers. BGMEA member factories account for $100 \%$ woven garment exports of the country and more than $95 \%$ of sweater exports, while around half of the light knitwear exports are made by them (ACD, 2016).

The Asian Center for Development organization has conducted the survey on 1204 workers of 173 BGMEA enlisted garments factories and average number of employees was near about 950 workers. The male and female employees' ratios of sweater factories, knitwear factories and other factories were 46:54, 42:58 and 30:70 respectively. The survey result showed that nearly 87 per cent of the workers migrated from 59 districts to the factory location from other districts and the rest were local workers. On an average, a garment worker monthly expenditure was around eleven thousand two hundred ninety nine taka and the garment employee expend 40 percent for food consumption, 30 percent for housing, 11 percent remitted to their parents. The statistics of the surveyed workers' assets were 86 per cent had mobile phone followed by 84 per cent have electric fans, 75 per cent have own homes, 68 percent had television and 28 percent had gold ornaments. The study also collected data about workers' literacy and found that 71 
percent can read and write while 83 percent can read and only 12 percent neither read nor write. Normally, garments worker incomes vary from 6000 taka to 12000 taka on the basis of skilled, semi-skilled and unskilled workers. It was also found in the analysis that a garments worker spends Taka 667 for children or siblings education, Taka 604 for health, Taka 526 for clothing, Taka 316 for mobile phone use, Taka 299 for cosmetics, and Taka 98 for entertainment. Approximately 40 percent of garments worker send money to their extended family members and the amount was Taka 3000. The collected data disclosed that about 84.2 per cent of the factories have their own doctors, 38.81 per cent have health workers, and 76 per cent factories also provide medicine. These facilities used by the 66 per cent of the workers when they were ill.

In the garment sector, exploitation of female employees starts from recruitment process by not giving the appointment letter (Absar, 2002). Women are considered differently in case of wages and promotions. The working condition of the factory is not congenial because of overcrowded workforce performing different activities in the same floor (Paul-Majumder and Begum, 2000).

Generally, some people do job for survival while others do job to increase the living standard. Female workers are working in the garments sector for different push and pull reasons (Kibria, 1998). Financial hardship, different types of household crises such as losing in the business, unemployment, illness or death of the chief source of the family income are considered as push factors while pull factors are related with the attractive forces which influence women to enhance their standard of living (Kibria, 1998).

Empowerment is ensured by raising voices. Female garments workers have limited voice not only in the home because of male domination but also at the work place because of absence of trade union (Ahmed, 2004: 38-41). Development denotes, in a wide sense, fortifying well-being and the satisfaction of human needs (Galtung, 1980). Therefore, in order to ensure development, it is necessary to remove all kinds of gender inequalities, because gender inequalities negatively affect the well-being (Klasen, 2000), and satisfaction of human needs.

The above literature demonstrates that garments sector has pivotal role in women empowerment especially for poor and rural women though it is not up to the mark. In these circumstances, the authors attempted to find out the level of women empowerment among the garments worker of Bangladesh.

Empowerment refers to boost decision making ability of individuals and groups and transform those decisions into reality (Narayan 2002). Resources, agency and achievements are three inter-related dimensions 
which comprises a person's decision making capability.

Resources mean material resources as well as social and human resources which help to increase the capability of decision making. In the boarder sense, resources are developed through a diversify social relationships such as family, market and community of the society. Right to entry or use such resources will narrate the rules and norms of administering distribution and exchange in different institutional arenas. In determining the principles of distribution and exchange certain actors authority over others according to the previously mentioned rules and norms hence distribution of 'allocative resources' embedded by the distribution of 'authoritative resources' (Giddens, 1979).

Sathar and Kazi (1997), for example, connect both 'access' and 'control' with having a say in decisions related to particular household resources. They measured two things such as 'access to resources' which is reflected on whether women participates in household expenses decisions and whether women can freely buy clothes, jewelry, and gifts for their relatives and 'control over resources' is calculated by knowing who kept household earnings and who has the authority in household expenditure. In Jejeebhoy's (1997) analysis resources are related to the concepts of 'access', 'control' and 'decision-making', where 'control' sometimes referring to ownership and decision-making.

Women's empowerment can be defined as controlling the key aspects of their lives (Kishor's (1997). It is very difficult to define control in one term because it has different meaning such as control explained in relation to resources, earnings and expenditure. Some other sees control as a selfreliance means self-dependency and some other sees decision making authority is a true indicator of control. Last but not the least some people believe that freedom to choice the life partner is also an indicator of controlling.

Measurement of agency comprises both positive and negative agency such as women's participation in public action, their mobility in the public domain, the occurrence of male viciousness and so on. Nonetheless, decision making agency is off and on use to measure agency hence decision making is the heart of conceptualizing power (Lukes, 1974; McElroy, 1992).

Here are some decision-making indicators which vary country to country. In Egypt, decision making power is measured on the basis of the decisions of food cooked, visits, children's education, household budget, children's health, use of family planning methods (Kishor, 1997).

In case of India, whether women have decision making power or not is judge by look at the decision making ability about disciplining the child; decisions about children's education and type of school, purchase of food; purchase of major household goods; purchase of small items of jewelry; and 
course of action if child falls ill (Jejeebhoy, 1997). The factors are different in

Zimbabwe where women's decision making ability depends on the decisions about spouse working outside; making a major purchase; and the number of children (Becker, 1997).

In Pakistan, decision making authority of women reflects the decision taken by the women about Children's marriage; major household purchases; Purchase of food; number of children; schooling of children; women's work outside the home; sale and purchase of livestock; household expenses; purchase of clothes, jewelry and gifts for wife's relatives (Sathar and Kazi, 1997). In Bangladesh context, women's decision making ability lies on ability to make small and large consumer purchases; house repair; taking in livestock for raising; leasing in of land; purchase of major assets (Hashemi et al., 1996).

Agency is the capacity to make meaningful choice and asset endowments are used as indicators of agency. These assets can be psychological, informational, organizational, material, social, financial, or human. Some assets are easy to measures while others are not. For example, it is difficult to access psychological assets (such as the capacity to envision) or social assets (such as social capital) than quantify human assets (such as skills or literacy) (Alsop, Ruth, Anirudh Krishna, and Disa Sjoblom. 2001). It is difficult to understand the interaction among assets for example, a single asset is ownership of land can affect a person's ability to make meaningful choices whereas education (a human asset) often gives an actor greater access to information (itself an asset) and at times improves his/her capacity to envision alternative options (a psychological asset).

The manifestation and operation of formal and informal institutions or rules of the game is an actor's of opportunity structure (North 1990, and Uphoff 1986). The presence and process of the formal and informal laws, regulations, norms, and customs determine whether individuals and groups have access to assets, and whether these people can use the assets to achieve desired outcomes (Freire 1973 and Fals Borda 1988).

Direct measures of empowerment can be made by assessing existence of choice, use of choice and achievement of choice. For example, to assess the degree of political empowerment of women, it is necessary to know (i) whether opportunities for political participation exist, such as whether elections are held, and, if so, (ii) whether women attempt to vote; and (iii) whether they actually vote. The use of choice involves measuring whether or not a person or group takes advantage of an opportunity to choose. The mother of a child can think to send her daughter to school if there is a school it means without existence of institution choice cannot be made (Alsop, Sjoblom, and Krishna 2001). 
The degree of empowerment is varying from level to level. Research demonstrates that individuals or communities empowered at the intermediary or macro level are not necessarily empowered at the local level (Fox 1996, Moore 2001, Moser, 1987).

Socio-economic dimension, familial dimensions and psychological dimensions are three important dimensions of women's empowerment (Malhotra et al., 2002). These dimensions are dynamic, interlinked and mutually reinforcing at household level and recognize the fact that the level of gender equality and development are directly proportional.

Six indicators of women's empowerment are contribution to household income, access to resources, ownership to assets, participation in household decision making, perception on gender awareness, and coping capacity to household shocks (Shahnaj Parveen and Ingrid-Ute Leonhäuser 2004). Financial contribution includes both farm activities and nonfarm activities. Access to resources narrates the right, scope, power or permission to use and get benefits from household resources and social resources. The third indicator of women empowerment is ownership of assets (both productive and non-productive) which means women have the capability to control their own assets and enjoy profits and advantages occurring form them. Participation in household decision making is the fourth factor which actually shows the women's participation in decision making process and also implementing the decision in different family and social matters. The fifth factor is the gender awareness which denotes the women consciousness about gender inequality and unfairness in the society. The sixth and the last indicator of women empowerment is the coping capacity to household shocks which means women's risk taking ability and crisis management capacity.

\section{Objectives of the study}

The main purpose of the study is to examine the relationship of Ready Made Garments sector's contribution to women empowerment in Bangladesh. The specific objectives are:-

(i) To examine the relationship between the readymade garments' contributions and women empowerment.

(ii) To find out the readymade garments contributions which is most significantly related to the women empowerment?

(iii) To make a rank among the readymade garments contributions on the basis of the association with the women empowerment.

(iv) To suggest some policy measures to be adopted by the planners and the decision makers. 


\section{Methodology}

With a view to conducting a research study, what is necessary is to design the research framework and select the appropriate research methodology. Given the nature of the present study, it was required to collect data both from the primary and the secondary sources. Secondary data were collected by consulting various documents, such as, Office-Order; Annual Reports, Employee profile, Employee data base prepared by Human Resource Department, and relevant Journals.

Interview technique was used with structured questionnaire for collection of primary data. The judgmental sampling procedure was used to select the sample units from different employees of different garments factories who were willing to respond to the questionnaire. Total numbers of respondents were two thousand selected from forty different factories of Gazipur and Savar districts of Dhaka division. These garments factories represent the total garments factories in Bangladesh. Before interviewing with the final questionnaire the author checked the questionnaire with 50 garments workers to find out whether the questionnaire was understandable and match with objectives or need improvements etc. The questionnaire is made of 35 questions and five questions for each variable. The data, thus collected, was analyzed keeping in mind the objectives of the study. And for hypothesis test the authors used multiple regression analysis with the help of SPSS.

\section{Model}

The authors have used the women empowerment as the dependent variable and the garments sector contributions are the independent variable like financial contribution, access to resources, ownership of assets, participation in household decision making, perception of gender awareness, and coping capacity to household shocks. The authors have run the OLS regression model to determine the significance level of the variables for women empowerment.

The basic model for the study was therefore as follows:

$W E=\alpha+\beta_{1} X_{1}+\beta_{2} X_{2}+\beta_{3} X_{3}+\beta_{4} X_{4}+\beta_{5} X_{5}+\beta_{6} X_{6}+\beta_{7} X_{7}+\beta_{8} X_{8}+\beta_{9} X_{9}+e$

Where, $\mathrm{WE}=$ Women Empowerment.

$\mathrm{X}_{1}=$ Financial Contributions

$\mathrm{X}_{2}=$ Access to Resources

$\mathrm{X}_{3}=$ Ownership of Assets

$\mathrm{X}_{4}=$ Participation in Household Decision Making

$\mathrm{X}_{5}=$ Perception of Gender Awareness

$\mathrm{X}_{6}=$ Coping Capacity to Household Shocks

And $\alpha$ is constant and $\beta_{1}, \beta_{2}, \beta_{3}, \beta_{4}, \beta_{5}, \beta_{6}$ are coefficients to estimate, and e is the error term, which the authors assumed as NIL for this research. 


\section{Hypotheisis}

Null Hypothesis (Ho): There is no relationship between women empowerment and readymade garments sector's contributions in Bangladesh.

Ho: $\mathrm{B} 1=\mathrm{B} 2=\mathrm{B} 3=-------=\mathrm{Bk}=0$ (Here, $\mathrm{B}=$ regression coefficient $)$

Alternative Hypothesis (Ha): There is a relationship between women empowerment and readymade garments sector's contributions in Bangladesh.

Ha: At least one B is not zero.

\section{Finding of the Study:}

\section{Background Information:}

In Ready Made Garments (RMG) sector, most of the employees in workers' level are female. Total numbers of respondents were 2000 female employees selected from forty different garments factories of Gazipur and Savar area out of which $0.08 \%$ are working in top level, $0.89 \%$ are in midlevel, $4.45 \%$ are in first level management and $94.58 \%$ are in operators' level. Nearly about 1700 respondents are from rural areas of Bangladesh whereas 300 are from urban places.

Respondents are of different age groups and two third of the respondents were in between 21 to 35 years of age followed by 246 respondents whose age below 20 but above 16. 144 respondents were belongs to 36 to 45 age group. Only 13 respondents were from oldest age group (56-65) followed by 46 respondents were from 46 to 55 age groups.

\section{Age of the Respondents}

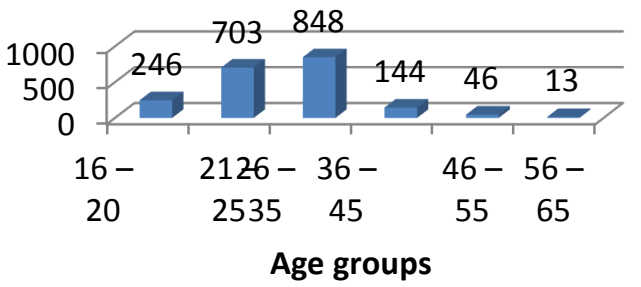

Number of respondents

Source: Field Survey, August 2017.

Women's marital status is one of the key factors which influencing women empowerment in a significant level. One third of the respondents were single followed by 603 married women and 295 separated women. The numbers of divorced women in this survey were 246 whereas widowed numbers were 154 . 


\section{Respondents Marital Status}

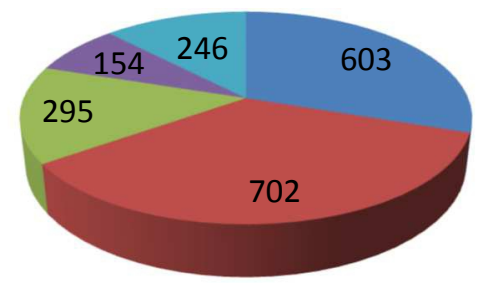

Married

- Single

Separated

Widowed

Divorced

Source: Field Survey, August 2017.

Educational qualification directly and indirectly related with women's empowerment. In this survey, the respondents' qualifications were varying from below secondary school certificate to graduate level. As most of the respondents were garments operators, sixty percent respondents were S.S.C pass, one fourth of the respondents were below S.S.C level and one eighth respondents were H.S.C pass and only twenty respondents were graduates.

\section{Educational Qualifications of the Respondents}
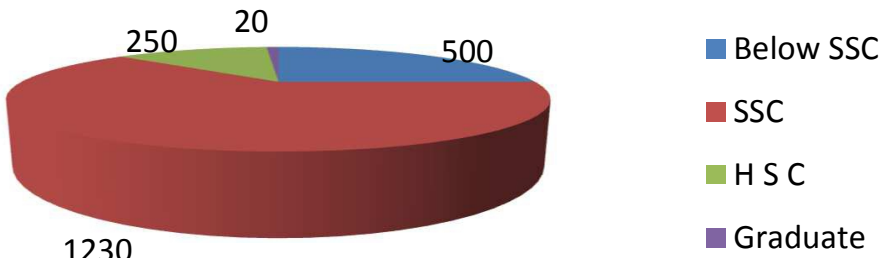

Source: Field Survey, August 2017.

\section{Discussion of the Findings:}

Women's empowerment in the family more or less depends on her financial contribution. However, this empowerment varies from family to family because each family consists of different family members which mean different attitude different personality. Three hundred seventy eight respondents contributed seventy to sixty percent of their total family expenditure followed by 343 respondents paid fifty to forty percent family expenditure and 324 respondents gave half of the family expenditure to their family. One sixth of the respondents gave thirty to forty percent of their family expenditure. It was noticeable that 300 respondents paid 90 to 80 percent of their family expenditure and 51 gave money to pay all the expenditure. 


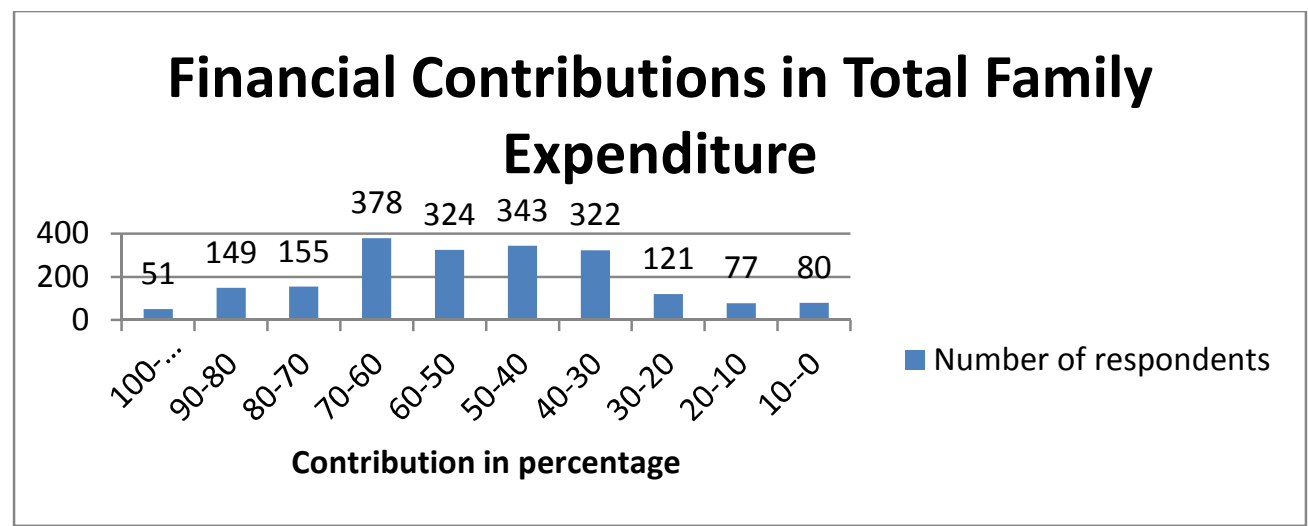

Source: Field Survey, August 2017.

In Bangladesh, traditionally most of the household decisions are taken by the men. However, due to the financial solvency of women helps them to participate in household decision making. In this survey, one fourth women participated in 20 to 10 percent of their family decision making followed by another one fourth women participated in 40 to 30 percent of their household decisions. Two hundred seventy seven respondents told that they participated half of their family decision and a good number of one fifty seven women gave their opinion in 60 to 50 percent of their household decision. One tenth of the respondents participated in 90 to 60 percent of their family decision. Less than ten percent household decisions were attended by 157 garments workers and the remaining 221 respondents attended only 30 to 20 percent decisions.

\section{Participation in Household Decision Making}

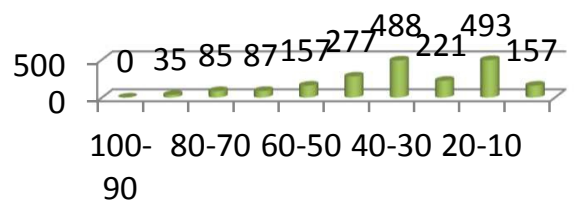

PHDM in Percentage

Source: Field Survey, August 2017.

Women empowerment vastly depends on handling resources which includes both household resources and social resources. The survey result showed that maximum respondents (1144) had 40 to 70 percent access to their resources and 387 respondents told they had 70 to 100 percent access to 
their resources whereas the remaining 469 garments workers had only 1 to 40 percent access of their resources.

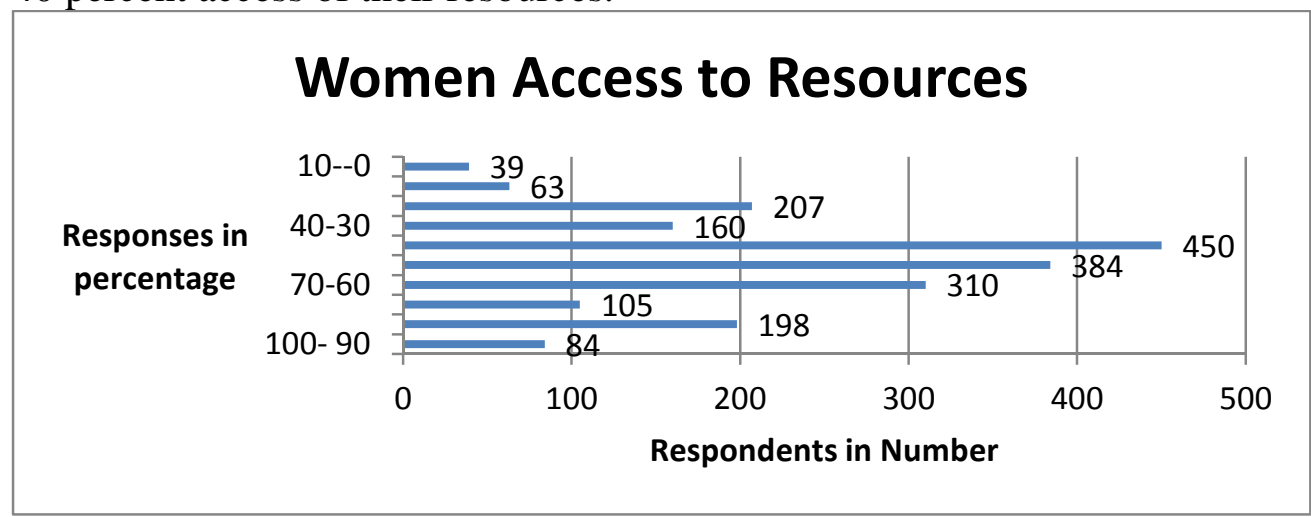

Source: Field Survey, August 2017.

Women's are not aware of their rights, scopes and gender inequality issues. To ensure empowerment women have to be more conscious about their rights and privileges. In this study, it had been found that almost all respondents were less than 50 percent conscious about gender awareness. Five hundred thirty eight respondents were only less than 10 percent conscious about gender inequality followed by 407 respondents whose gender awareness belongs to 10 to 20 percent. One eighth garments workers showed 20 to 30 percent awareness and 30 to 40 percent awareness showed by one fourth of the samples. The remaining 213 respondents were 50 percent conscious about their rights and 70 percent awareness showed by 65 respondents.

\section{Perception of Gender Awareness}

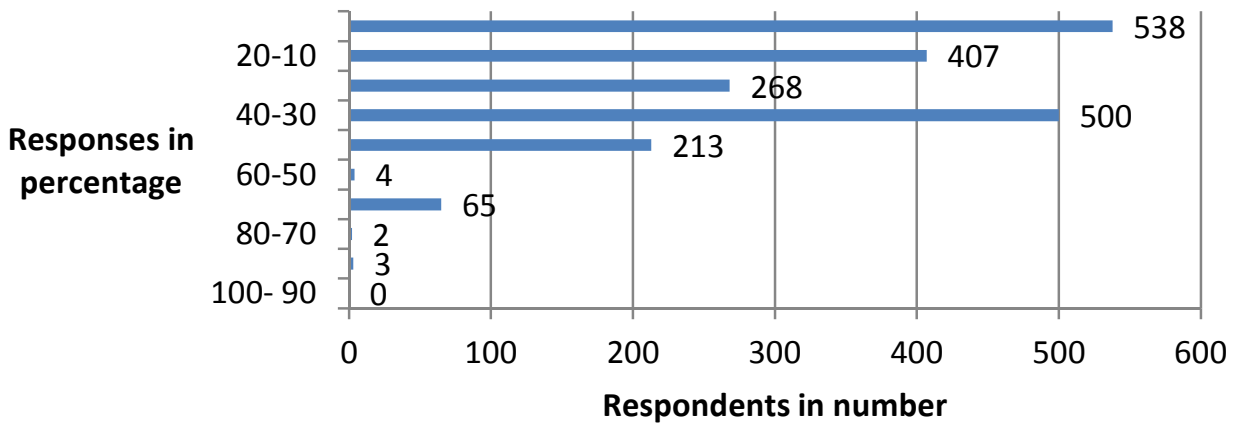

Source: Field Survey, August 2017.

Whether women are truly empowered or not it reflects on their coping capacity to shocks. The collected data showed that total 1751 
respondents mean 88percent respondents coping capacity to shocks lies in between 0 to 30 percent. The 91 respondents coping capacity in risky situation were 30 to 40 percent. It had been found that 24 samples were highest coping capacity in shocking situation and that were 50 to 60 percent followed by 134 respondents who had 40 to 50 percent coping capacity with crisis situation.

\section{Respondents' coping capacity to shocks}

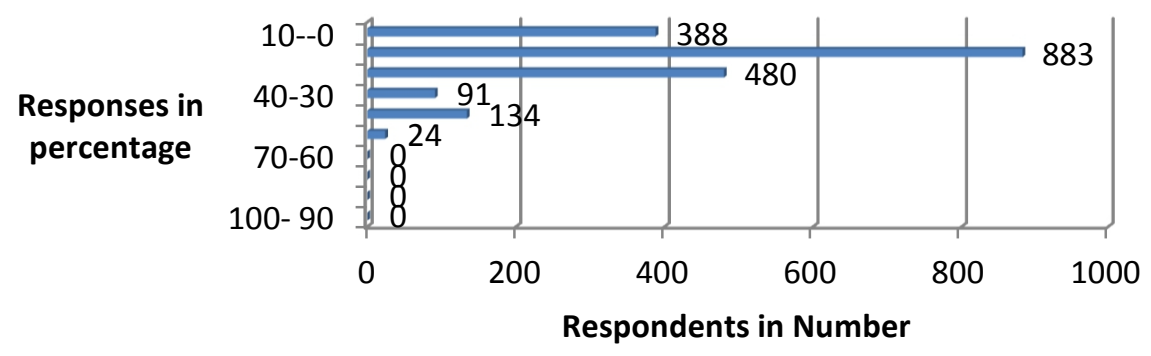

Source: Field Survey, August 2017.

To consider the social and economic conditions of the respondent, they gave their opinion about women empowerment in their life. Only 26 respondents felt that they were empowered by 70 to 80 percent and the second position achieved by 88 participants with 60 to 70 percent empowerment. The survey result showed that 236 respondents belongs to 50 to 60 percent empowered level and 492 garments employees of the samples enjoyed 40 to 50 percent empowerment. It was the opinion of 905 respondents that they had the opportunity to exercise only 30 to 20 percent of empowerment. The remaining 253 garment employees thought that they were empowered by only 0 to 20 percent.

\section{Respondents Opinion About Women Empowerment}

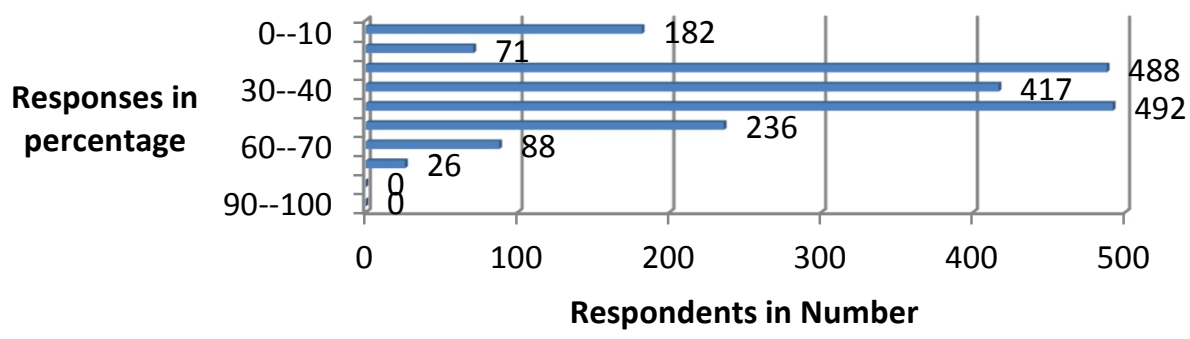

Source: Field Survey, August 2017. 
Woman empowerment (10\% to $100 \%)$ related to female employees' financial contribution to family, (5\% to 100\%) with employees' access to resources and (5\% to $80 \%)$ related with employees' participation in household decision making. Other factors like perception of gender awareness (0\% to $80 \%)$ related with employees' empowerment. Employees' ownership of assets and coping capacity to household shocks shows comparatively less relation with employees' empowerment.

Table 3: Female Employees' Empowerment vis-à-vis Ready Made Garments' Contributions

\begin{tabular}{|c|c|c|c|c|}
\hline $\begin{array}{c}\text { Garments employees' responses } \\
\text { on }\end{array}$ & Minimum & Maximum & Mean & Std. Deviation \\
\hline $\begin{array}{c}\text { Financial contribution to family } \\
\text { in percentage }\end{array}$ & .10 & 1.00 & .5644 & .21047 \\
\hline Access to Resources & .05 & 1.00 & .5029 & .21046 \\
\hline Ownership of Assets & .00 & .80 & .2723 & .18179 \\
\hline $\begin{array}{c}\text { Participation in household } \\
\text { decision making }\end{array}$ & .05 & .80 & .3063 & .19791 \\
\hline Perception of gender awareness & .00 & .80 & .2010 & .16298 \\
\hline $\begin{array}{c}\text { Coping capacity to household } \\
\text { shocks }\end{array}$ & .05 & .60 & .1542 & .10490 \\
\hline
\end{tabular}

Source: Field Survey, August 2017.

\section{MODEL SUMMARY}

Table 4: Regression Analysis

\begin{tabular}{|c|c|c|c|c|}
\hline Model & R & R Square & Adjusted R Square & Std. Error of the Estimate \\
\hline 1 & $.886^{\mathrm{a}}$ & 0.785 & 0.785 & .06786 \\
\hline
\end{tabular}

Source: Field Survey, August 2017

From above calculation it shows that there was a significant correlation between dependent variable and independent variables. And at $5 \%$ level of significance the correlation is $88.6 \%$.

Here, adjusted R Square is 0.785 which told us that about 78 percent variation of dependent variable is explained by independent variables included in this model. And the independent variables of this model are financial contribution to family, access to resources, ownership of assets, participation in household decision making, perception of gender awareness, and coping capacity to household shocks.

Table 5: ANOVA Test

\begin{tabular}{|c|c|c|c|c|c|c|}
\hline Model & & Sum of Squares & df & Mean Square & F & Sig. \\
\hline 1 & Regression & 33.597 & 6 & 5.600 & 1215.997 & .000 \\
& Residual & 9.177 & 1993 & .005 & & \\
& Total & 42.775 & 1999 & & & \\
\hline
\end{tabular}

Source: Field Survey, August 2017. 
From ANOVA test it shows that the table Sig. value 0.05 is greater than the calculated Sig. Value 0.000. So, it rejects the null hypothesis at 5\% level of significance and also $1 \%$ level of significance. It means, there was a significant relation between dependent variable and independent variables. Therefore, female employees' empowerment depends on financial contribution to family, access to resources, ownership of assets, participation in household decision making, perception of gender awareness, and coping capacity to household shocks. However, it does not mean that all contributions of readymade garments have significant impact on employees' empowerment. For this, the authors went for coefficient analysis for further study.

Table 6: Results of Multivariate (OLS) Analysis: Female Employees' Empowerment (Dependent variable) vis-à-vis Ready Made Garments' Contributions (Independent Variables).

\begin{tabular}{|c|c|c|c|c|c|}
\hline $\begin{array}{c}\text { Readymade garments' } \\
\text { contributions to women } \\
\text { empowerment }\end{array}$ & $\begin{array}{c}\text { Unstandardized } \\
\text { Coefficients }\end{array}$ & $\begin{array}{c}\text { Standardized } \\
\text { Coefficients }\end{array}$ & $\mathrm{T}$ & Sig. \\
\hline $\begin{array}{c}\text { i) Financial contribution to family } \\
\text { in percentage }\end{array}$ & $\mathrm{B}$ & Std. Error & Beta & & \\
\hline ii) Access to Resources & .102 & .015 & .629 & 29.281 & .000 \\
\hline iii) Ownership of Assets & -.021 & .012 & -.025 & -1.729 & .084 \\
\hline $\begin{array}{c}\text { iv) Participation in household } \\
\text { decision making }\end{array}$ & .125 & .012 & .169 & 10.602 & .000 \\
\hline v) Perception of gender awareness & .052 & .013 & .058 & 4.155 & .000 \\
\hline $\begin{array}{c}\text { vi) Coping capacity to household } \\
\text { shocks }\end{array}$ & -.034 & .018 & -.024 & -1.902 & .057 \\
\hline
\end{tabular}

Source: Field Survey, August 2017.

Coefficient analysis shows the relationship between dependent variable and each independent variable. According to Sig. value employees' financial contribution to family, access to resources, participation in household decision making and perception of gender awareness have significant influence on employees' empowerment. Here, table Sig. value is 0.05 which is greater than calculated Sig. value 0.000, 0.000, 0.000and 0.000 respectively. However, the calculated Sig. value of Ownership of assets and coping capacity to household shocks are greater than the Table Sig. value. And then, these factors have some impact on female employees' empowerment but these are not significant.

At last final model includes four independent variables financial contribution to family, access to resources, participation in household decision making and perception of gender awareness which have significant impact on employees' empowerment on the basis of t value $>=2.146$. 
Here,

$\beta 1$ (Financial contribution to family) $=0.629$, i.e., $100 \%$ change in financial contribution to family leads to $62.9 \%$ change in women empowerment.

$\beta 2$ (Participation in household decision making) $=0.169$, i.e., $100 \%$ change in participation in household decision making leads to $16.9 \%$ change in women empowerment.

$\beta 3$ (Access to resources) $=0.146$, i.e., $100 \%$ change in access to resources leads to $14.60 \%$ change in women empowerment.

$\beta 4$ (Perception of gender awareness) $=0.058$ i.e., $100 \%$ change in perception of gender awareness leads to $5.8 \%$ change in women empowerment.

According to significant correlation, between dependent variables and each independent variable, we can arrange it in order from most significant correlation to less significant correlation.

Table 7: Dependency of female employees' empowerment on readymade garments sector

Factors

Value of $\beta$

Financial contribution to family

Participation in household decision making

Access to resources

Perception of gender awareness
0.629

0.169

0.146

0.058
Rank order on the basis of significant

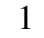

2

3

4

Source: Field Survey, August 2017

\section{Conclusion}

It has been observed from the findings of the conducted study that ready-made garments have significant effects on women empowerment. In general, women's financial contribution to family is the deciding factor of their empowerment though their communications skills and understanding ability of the situation helps them to participate in household decision making and access to resources which are also have great impact on their empowerment. Therefore, to enhance the women empowerment, more garments factories needs to establish by complying country's prevailing rules and regulations and buyers demand and create more employment for female workers. In this study, four major factors financial contribution to family, participation in household decision making, access to resources and perception of gender awareness which represented ready-made garments contribution to women empowerment. The study reveals that the most significantly related female employees' empowerment is the financial contribution to family. Participation in household decision making is the second most significant variable which contributes to increases women empowerment followed by access to resources and perception of gender awareness variables which also have noticeable impact on women 
empowerment. Other factors have no significant contribution to women empowerment because of the male domination society and its structure although the general perception of society has been changed slowly towards women empowerment. The collected data was the representation of the institutional practices of different garments company as well as the personal characteristics of the respondent such as age, marital status, education etc. Therefore, the study suggests doing in depth study on this issue covering other types of institutions and larger sample size. To consider all these circumstances the results of the study may be useful in increasing women empowerment by focusing more support to female workers of garment factories by their management and also by the buyer and the BGMEA.

\section{Policy Recommendations:}

Here the authors proposed to deal with policy issues arising out of the study and make some specific recommendations as follows:-

(i) In most of the cases, woman who has financial solvency and can contribute a significant amount to her family generally enjoy the freedom to take decisions about herself and also for her family. So, the owners and managers of the garments factories have to maintain a comfortable working environment by practicing proper human resource management practices in their garments factories.

(ii) Access to resources is one of the leading factors of women empowerment and Garments Company can establish facilities such as school, child care, clinic, and restaurant and request the banks to establish branch in nearby location which definitely help female workers to easy access to resources and boost empowerment.

(iii) More emphasis should be given on equal employment opportunity and ensure zero tolerance for sexual harassment and also create a victim support center for women in each factory which definitely enhance women empowerment.

If all these suggestions are accepted and implemented by the policy makers and the owners of the garments factory it is expected that women empowerment would increase to a large extent.

\section{References:}

1. Absar, S. S. (2001). "Problems Surrounding Wages: The Readymade Garment Sector in Bangladesh."Labor Management in Development Journal, Vol. 2, No. 7, PP. 3-17

2. Absar, S. S. (2002). "Women Garment Workers in Bangladesh." Economic and Political Weekly, Vol.37, No.29, 3012-3016.

3. ACD (2016), Garments workers in Bangladesh: Social impact of the garments industry, New Age, January 13, 2016. 
4. Ahmed, F. E. (2004).“The Rise of the Bangladesh Garment Industry: Globalization, Women Workers, and Voice.’NWSA Journal,Vol.16, No.2, PP.34-45.

5. Ahmed, J. U. and Hossain, T. (2009). "Industrial Safety in the Readymade Garment Sector: A Developing Country Perspective".Sri Lankan Journal of Management,Vol.14, No.1,PP.1-13.

6. Alsop, Ruth, Anirudh Krishna, and Disa Sjoblom. 2001. Inclusion and Local Elected Governments: the Panchayat Raj System in India. Social Development Paper No. 27, World Bank, Washington, DC.

7. Balk, D. (1997) 'Change Comes Slowly for Women in Rural Bangladesh', Asia-Pacific Population \& Policy 41: 4. Honolulu, Hawaii (USA): East-West Centre.

8. Cain M., Khanam , S.R. and Nahar S (1979)," Class patriarchy and women's work in Bangladesh" Population and Development Review, Vol 5, No. 3.

9. DFID (2000) Report on Poverty Elimination and the Empowerment of Women, UK: Stairway Communications.

10. Galtung, J. (1980).'The Changing Interface between Peace and Development in a Changing World."Security Dialogue, Vol.11,No. 2, PP. 145-149.

11. Galtung, J. (1990). “Cultural Violence.”Journal of Peace Research, Vol.27, No.3, PP.291-305.

12. Giddens, A. (1979) Central Problems in Social Theory. London: Macmillan Press.

13. Hashemi, S. M., S. R. Schuler and A. P. Riley (1996) 'Rural Credit Programs and Women's

14. Empowerment in Bangladesh', World Development 24(4): 635 \pm 53 .

15. Ho, K. H. (2007)."Structural Violence as a Human Rights Violation.’'Essex Human Rights Review, Vol.4, No. 2,1-17.

16. Jejeebhoy, S. (1997), 'Operationalising Women's Empowerment: the Case of Rural India', paper presented at the Seminar on Female Empowerment and Demographic Processes, Lund (20 24 April).

17. Kabeer, N. (1999). "Resources, Agency, Achievements: Reflections on the Measurement of Women's Empowerment.'Development and Change, Vol.30, No.3, PP.435-464.

18. Kibria, N. (1995). "Culture, Social Class, and Income Control in the Lives of Women Garment Workers in Bangladesh." Gender and Society, Vol.9, No.3,PP.289-309.

19. Yardley, J. (2013). Report on Deadly Factory Collapse in Bangladesh Finds Widespread Blame. The New York Times

20. Kishor, S. (1997) 'Empowerment of Women in Egypt and Links to the Survival and Health of their Infants', paper presented at the 
Seminar on Female Empowerment and Demographic Processes, Lund (20 \pm 24 April).

21. Klasen, S. (2000).Does Gender Inequality Reduce Growth and Development? Evidence from Cross-Country Regressions.LudwigMaximilians-Universität

22. Lukes, S. (1974) Power: A Radical View. London: Macmillan.

23. Narayan, D., ed. 2002. Empowerment and Poverty Reduction: A Sourcebook.Washington, DC: The World Bank.

24. Paul-Majumder, P. (2000)."Violence and Hazards Suffered by Women in Wage employment."Empowerment,Vol. 7, Women for Women, Dhaka, Bangladesh. PP. 1-30

25. Ruth Alsop \& Nina Heinsohn,(2005), Measuring Empowerment in Practice: Structuring Analysis and Framing Indicators, World Bank Policy Research Working Paper 3510, February 2005.

26. Sathar, Z. A. and S. Kazi (1997) Women's Autonomy, Livelihood and Fertility. A Study of Rural Punjab. Islamabad: Pakistan Institute of Development Studies.

27. Shahnaj Parveen and Ingrid-Ute Leonhäuser, (2004), Empowerment of Rural Women in Bangladesh: A Household Level Analysis, Conference on Rural Poverty Reduction through Research for Development and Transformation, Deutscher Tropentag- Berlin, Germany,

Sebstad, J. and M. Cohen (2000) 'Microfinance, Risk Management, and Poverty', AIMS Paper, Management Systems International, Washington, D.C. 